\title{
Kebijakan Hukum Pidana dalam Pemidanaan Tindak Pidana Illegal Logging
}

\section{Criminal Policy in Illegal Logging Criminal}

\author{
Arto Siswahyudi \\ Kepolisian Republik Indonesia, Kesatuan Pelaksanaan Pengamanan Pelabuhan (KPPP) \\ E-mail: artosiswahyudi@gmail.com \\ Oheo K. Haris \\ Pascasarjana Universitas Halu Oleo \\ E-mail: oheo.haris@uho.ac.id \\ Sabrina Hidayat \\ Pascasarjana Universitas Halu Oleo \\ E-mail: sabrinahidayat@uho.ac.id
}

\begin{abstract}
This paper addressed at answering the problems of fine sanction towards the state as the victim. Besides, it's applied for criminal sanction firstly instead of either administrative or private sanction. This study applied a normative study was carried out with a statutory approach method and a conceptual approach as well as a case approach. The results showed that: 1) the criminal sanction of paying replacement money to the victim is a form of criminal law policy. Hence, criminal law tended to provide criminal sanctions to deter the perpetrator, but it has less impact on the victim. The victim referred to in this case is the state (not an individual) so that in the end the replacement money will be paid by the country that will receive it. 2) Criminal sanctions as the last law enforcement effort are applied after administrative and civil sanctions are deemed unsuccessful in resolving illegal logging.
\end{abstract}

Keywords: Criminal Law; Policy; Illegal Logging

Abstrak: Penelitian ini ditujukan untuk menjawab permasalahan yang diajukan atas sanksi denda terhadap negara sebagai korban. Studi ini menggunakan penelitian yang berbentuk yuridis normatif dengan metode pendekatan perundang-undangan dan pendekatan konseptual serta pendekatan kasus. Hasil penelitian menunjukkan bahwa: 1) Sanksi pidana pembayaran uang pengganti kepada korban sebagai bentuk kebijakan hukum pidana. Sebab selama ini dalam hukum pidana cenderung memberikan sanksi pidana untuk menjerakan pelaku, tetapi kurang berdampak pada korban. Korban yang dimaksud dalam hal ini adalah negara (bukan individu) sehingga akhirnya uang pengganti yang dibayarkan tersebut negara yang akan 
menerimanya. 2) Sanksi pidana sebagai upaya penegakan hukum terakhir yang diterapkan setelah sanksi administrasi dan sanksi perdata dianggap tidak berhasil menyelesaikan illegal logging.

Kata kunci: Kebijakan; Hukum Pidana; Illegal Logging

\section{PENDAHULUAN}

Indonesia sebagai negara yang dikaruniai kekayaan sumber daya alam yang melimpah, patut untuk disyukuri oleh seluruh bangsa ini. Kekayaan atas sumber daya alam tersebut, harus diurus, dikelola, dan dimanfaatkan dengan sebaik-baiknya. ${ }^{1}$ Tanggung jawab pemerintah bukan hanya terletak pada pembentukan aturan-aturan hukum semata, tetapi juga berperan secara aktif dalam menciptakan iklim pemerintahan yang baik, terbuka, dan bertanggungjawab dalam mengelola sumber daya alam Indonesia. Pemerintah dalam aspek ketatanegaraan merupakan penentu maju dan mundurnya suatu negara. ${ }^{2}$ Oleh karena itu, dalam mengeksploitasi hutan, baik pada kawasan hutan lindung maupun hutan produksi memerlukan suatu pendekatan yang bijak agar hutan tetap berada pada posisinya sebagai penyeimbang lingkungan. ${ }^{3}$

Penebangan liar atau tindak pidana illegal logging adalah praktik ilegal terhadap kegiatan kehutanan yang berkaitan dengan pemanenan, pengelolaan serta penebangan dan perdagangan kayu yang tidak sesuai dengan hukum Indonesia atau kegiatan kehutanan yang belum mendapat izin dan merusak hutan. Seperti yang dimaksudkan dalam Pasal 1 Ayat (4), ayat (6) dan Ayat (10) Undang-undang Nomor 18 Tahun 2013 Tentang Pencegahan dan Pemberantasan Perusakan Hutan, praktik ini tergolong dalam kejahatan terorganisir. Karena modusnya melibatkan cukong dan para petugas baik itu di tingkat pusat atau daerah dengan kata lain di balik kegiatan tersebut ada pihak oknum anggota aparatur negara dan sebagian instalasi pemerintah juga bermain di dalamnya. Di sisi lain penegakan hukum tindak pidana dibidang kehutanan yang diatur dan dirumuskan dalam Undang-Undang No. 18 Tahun 2013 tentang Pencegahan dan Pemberantasan Perusakan Hutan, tidak menyebutkan secara jelas apa yang dimaksudkan dengan illegal logging

1 Johnny Salam, "Penanggulangan Kejahatan Illegal Logging di Provinsi Sulawesi Tengah", Tadulako Law Review, Volume 1 Issue 1, June 2016, hlm 1.

2 Herman, "Upaya Non Penal dalam Penanggulangan Tindak Pidana Korupsi”, Halu Oleo Law Review, Volume 2 Issue 1, March 2018, hlm. 307

3 Bimbi Pratiwi, “Sistem Penegakan Hukum Terhadap Tindak Pidana Illegal Logging (Studi Di KPH Bojonegoro Perum Perhutani Unit II Jawa Timur Dan Kepolisian Resort Bojonegoro", Jurnal Hukum Fakultas Hukum Universitas Brawijaya, Mei 2015, hlm 1. 
tersebut, dalam artian tidak dirumuskan secara limitatif (yang bersifat membatasi), sehingga banyak para praktisi hukum yang menafsirkan illegal logging sendiri-sendiri.

Di sisi lain penegakan hukum tindak pidana di bidang kehutanan yang diatur dan dirumuskan dalam Undang-undang No. 18 Tahun 2013 Tentang Pencegahan dan Pemberantasan Perusakan Hutan, tidak menyebutkan secara jelas apa yang dimaksudkan dengan illegal logging tersebut, dalam artian tidak dirumuskan secara limitatif (yang bersifat membatasi), sehingga banyak para praktisi hukum yang menafsirkan illegal logging sendiri-sendiri.

Lemahnya penegakan hukum memunculkan keprihatinan masyarakat. Oleh karena itu pemerintah harus memperbaiki kinerja penegak hukum oleh aparat penegak hukum, termasuk dalam menangani kasus illegal loging dan tindak pidana di bidang kehutanan yang lainnya. ${ }^{4}$

Sehubungan dengan hal-hal yang dikemukakan di atas, maka jika hukum merupakan bagian integral dari manusia, itu berarti, tata hukum mesti mengacu pada penghormatan dan perlindungan bagi keluhuran martabat manusia. Tujuan hukum pidana adalah (1) untuk melindungi kepentingan individu dari kesewenang-wenangan penguasa; (2) melindungi masyarakat dari kejahatan. ${ }^{5}$ Perbuatan pidana harus terdiri dari unsurunsur lahiriah (fakta) oleh perbuatan adanya kelakuan serta akibat yang ditimbulkan karenanya. Dua hal tersebut yaitu kelakuan dan akibat. ${ }^{6}$ Kepastian hukum dan keadilan merupakan tuntutan hakikat hukum itu sendiri, bukan hanya sekedar tuntutan moral perbuatan pidana itu dapat disamakan dengan criminal act, jadi berbeda dengan strafbaar feit, yang meliputi pula pertanggungjawaban pidana. ${ }^{7}$ Hakikat dan kepastian hukum dalam menentukan adanya inisiatif suatu pemerintah adalah memastikan dalam tindakan tersebut adanya suatu prinsip legalitas hukum. ${ }^{8}$ Dalam hal ini aparat penegakan hukum bertindak sesuai dengan norma-norma hukum, bukan mengikuti kepentingan pihak-pihak tertentu. Peningkatan integritas moral dan profesionalisme aparat penegak hukum, kesadaran

4 Bambang Tri Bawono, Anis Mashdurohatun, "Penegakan Hukum Pidana di Bidang Illegal Logging Bagi Kelestarian Lingkungan Hidup Dan Upaya Penanggulangannya", Jurnal Hukum Fakultas Hukum Unissula, Vol XXVI, No. 2, Agustus 2011, hlm 3.

5 Kuswardani, Handrawan, Widhia Kusuma Wardhani, "Hak Reproduksi Perempuan dan Hukum Pidana", Halu Oleo Law Review, Volume 3 Issue 2, September 2019, hlm. 214.

6 Moeljatno. Asas-Asas Hukum Pidana (Edisi Revisi), Jakarta: Rineka Cipta, 2015. hlm. 64-69.

7 Nikmah Fitriah, "Tinjauan Yuridis tentang Kriteria Pencemaran dan Perusakan Lingkungan Menurut UU No. 32 Tahun 2009 Tentang Pengelolaan Lingkungan Hidup", Halu Oleo Law Review, Volume 1 Issue 2, September 2017, hlm. 228.

8 Oheo K. Haris, "Good Governance (Tata Kelola Pemerintahan Yang Baik) dalam Pemberian Izin oleh Pemerintah Daerah di Bidang Pertambangan", Yuridika, Volume 30 No 1, Januari 2015, hlm. 60. 
hukum, mutu pelayanan serta tidak adanya kepastian hukum dan keadilan sehingga mengakibatkan supremasi hukum tidak mungkin dapat diwujudkan. Tekad untuk memberantas segala bentuk penyelewengan sesuai tuntutan reformasi seperti korupsi, kolusi, nepotisme, serta kejahatan di bidang lingkungan dan penyalahgunaan kekuasaan belum diikuti langkah-langkah nyata dalam menerapkan dan menegakkan hukum, terjadinya campur tangan dalam proses peradilan, serta tumpang tindih dan kerancuan hukum mengakibatkan terjadinya krisis hukum.

Pembangunan di bidang ekonomi harus diikuti oleh perkembangan di bidang hukum sejalan dengan peningkatan di bidang industri dalam negeri. Peningkatan di bidang ekonomi tersebut apabila tidak disertai perbaikan dan pengelolaan lingkungan secara baik, dapat mengakibatkan terjadinya kerusakan hutan yang semakin parah dan cenderung meningkat dari tahun ke tahun akibat kegiatan eksploitasi hutan yang semakin tidak terkendali. Kerusakan hutan antara lain disebabkan karena perbuatan illegal logging pada hal bertahun-tahun Pemerintah berusaha memberantas illegal logging tersebut, hal ini dimanifestasikan dengan berkali-kali mengubah dan menambah peraturan-peraturan di bidang kehutanan, termasuk peraturan mengenai tindak pidana illegal logging.

Tindak pidana illegal logging merupakan suatu aktivitas atau kegiatan penebangan kayu di dalam kawasan hutan yang dilakukan oleh seseorang, kelompok ataupun atas nama perusahaan yang tidak berdasarkan izin atau prosedur tata cara penebangan yang diatur dalam peraturan perundang-undangan yang dikeluarkan oleh pemerintah atau instansi yang diberi kewenangan untuk itu dalam hal ini instansi Kehutanan. Dengan demikian, illegal logging tidak dapat dibenarkan jika tidak mengikuti prosedur penebangan yang benar dan tidak berdasarkan ketentuan yang berlaku karena dapat menyebabkan kerusakan kelestarian lingkungan. Masalah illegal logging merupakan salah satu bentuk kejahatan di bidang kehutanan, yakni melakukan penebangan ilegal terhadap kayu-kayu di hutan-hutan milik negara. Penegakan hukum terhadap tindak pidana di bidang kehutanan sampai saat ini belum berjalan efektif seperti yang diharapkan oleh masyarakat banyak. Di beberapa daerah dalam penyelesaian pembalakan kayu masih sering terjadi kolusi antara pengusaha dengan aparat hukum dan aparat keamanan, sehingga penegakan hukum menjadi mandek (berhenti). Ironisnya tidak sedikit aparat hukum yang justru menjadi backing terhadap sindikat dan kelompok kejahatan pembalakan kayu tersebut, sehingga sulit diberantas. Hukum Pidana sebagai bagian dari hukum publik bertujuan untuk melindungi kepentingan umum, bukan kepentingan perorangan. Apabila terjadi kejahatan maka negara 
berkewajiban untuk mengambil tindakan hukum dengan menyeret pelakunya ke pengadilan meski korban tidak menuntut. Penegakan hukum pidana dimaksudkan untuk memulihkan keadaan yang rusak akibat kejahatan yang dilakukan oleh seseorang. Apabila penegakan hukum tidak dapat berjalan dengan baik maka akan timbul keresahan. Masyarakat terus terancam keselamatannya karena pelaku kejahatan belum diadili. Keresahan tersebut dapat bermuara pada munculnya tindakan main hakim sendiri terhadap pelaku kejahatan.

Lemahnya penegakan hukum memunculkan keprihatinan masyarakat. Oleh karena itu pemerintah harus memperbaiki kinerja penegak hukum oleh aparat penegak hukum, termasuk dalam menangani kasus illegal loging dan tindak pidana di bidang kehutanan yang lainnya. Pemerintah harus konsisten dalam menegakkan hukum terhadap setiap pelaku pelanggaran hukum di bidang kehutanan. Pemerintah harus melakukan reformasi dalam penegakan hukum di Indonesia. ${ }^{9}$ Keberhasilan penegakan hukum bergantung pada beberapa hal, yaitu: ${ }^{10}$

1. Tersedianya perangkat hukum yang baik dan lengkap;

2. Mereformasi mental aparat penegak hukum;

3. Penyediaan sarana dan prasarana hukum yang memadai;

4. Menata kultur hukum di masyarakat.

Secara faktual, kerusakan hutan di tanah air yang cukup memprihatinkan. Berdasarkan catatan Kementerian Kehutanan Republik Indonesia, sedikitnya 1,1 juta hektar atau 2\% dari hutan Indonesia menyusut tiap tahunnya. Data Kementerian Kehutanan menyebutkan dari sekitar 130 juta hektar hutan yang tersisa di Indonesia, 42 juta hektar di antaranya sudah habis ditebang. Kerusakan atau ancaman yang paling besar terhadap hutan alam di Indonesia adalah penebangan liar, alih fungsi hutan menjadi perkebunan, kebakaran hutan dan eksploitasi hutan secara tidak lestari baik untuk pengembangan pemukiman, industri, maupun akibat perambahan. Kerusakan hutan yang semakin parah menyebabkan terganggunya keseimbangan ekosistem hutan dan lingkungan di sekitarnya. Contoh nyata yang frekuensinya semakin sering terjadi adalah konflik ruang antara satwa liar dan manusia. Rusaknya hutan habitat satwa liar menyebabkan mereka bersaing dengan manusia untuk mendapatkan ruang mencari makan dan hidup, yang sering kali berakhir

9 Bambang Tri Bawono, Anis Mashdurohatun, Op. Cit., hlm 3.

10 Suriansyah Murhaini, Penegakan Hukum Terhadap Kerjahatan di Bidang Kehutanan, Yogyakarta: Laksbang Grafika, 2012, hlm. 4 
dengan kerugian bagi kedua pihak. Rusaknya hutan telah menjadi ancaman bagi seluruh makhluk hidup. ${ }^{11}$

Gambaran kerusakan hutan juga terjadi di wilayah Sulawesi Tenggara sudah cukup mengkhawatirkan. Berdasarkan data dari Departemen Kehutanan (Dishut) Sulawesi Tenggara dari 3 juta hektar hutan, 300 ribu hektar di antaranya rusak parah. Kondisi terparah terjadi di empat kabupaten, yakni Konawe Utara (18.583 hektar rusak), Konawe Selatan (14.545 hektar), Kolaka (12.442 hektar) dan Kolaka Timur (12.101 hektar). Ke empat kabupaten tersebut adalah daerah kawasan hutan yang lebih luas dibandingkan dengan daerah yang lain. Kerusakan hutan yang terjadi disebabkan banyak faktor. Namun, faktor penyebab paling utama adalah akibat illegal logging yang semakin marak terjadi. ${ }^{12}$

Melihat fenomena tersebut, pemerintah secara yuridis melalui Inpres Nomor 4 Tahun 2005 Tentang Pemberantasan Penebangan Kayu Secara Ilegal di Kawasan Hutan dan Peredarannya Di Seluruh Wilayah Republik Indonesia, bertekad untuk memberantas illegal logging sampai ke akar-akarnya melalui kerja sama komprehensif dari berbagai instansi pemerintah. Aktivitas illegal logging saat ini berjalan dengan lebih terbuka, transparan dan banyak pihak yang terlibat dan memperoleh keuntungan dari aktivitas pencurian kayu, modus yang biasanya dilakukan adalah dengan melibatkan banyak pihak dan secara sistematis dan terorganisir. Pada umumnya, mereka yang berperan adalah buruh/penebang, pemodal (cukong), penyedia angkutan dan pengaman usaha (sering kali sebagai pengaman usaha adalah dari kalangan birokrasi, aparat pemerintah, polisi, TNI).

Illegal loging terjadi karena adanya kerja sama antara masyarakat lokal berperan sebagai pelaksana di lapangan dengan para cukong bertindak sebagai pemodal yang akan membeli kayu-kayu hasil tebangan tersebut, adakalanya cukong tidak hanya menampung dan membeli kayu-kayu hasil tebangan namun juga menyuplai alat-alat berat kepada masyarakat untuk kebutuhan pengangkutan. ${ }^{13}$

Untuk mengatasi maraknya tindak pidana illegal logging jajaran aparat penegak hukum (penyidik Polri maupun penyidik PPNS yang lingkup tugasnya bertanggungjawab terhadap pengurusan hutan, Kejaksaan maupun Hakim) telah mempergunakan Undangundang Nomor 18 Tahun 2013 tentang pencegahan dan perusakan kehutanan sebagai

11 Nurul Arifin, “Bagaimana Hutan Indonesia Sebagai Paru-Paru Dunia di Masa Depan?”, Good News From Indonesia, https://www.goodnewsfromindonesia.id/2018/01/12/bagaimana-hutan-indonesia-sebagaiparu-paru-dunia-di-masa-depan, diakses pada tanggal 29 Mei 2020.

12 "Empat Kabupaten di Sultra Darurat Kerusakan Hutan", Kendari Pos, https://www.facebook.com/watch/?v=272751250178907, diakses pada tanggal 29 Mei 2020.

13 Tuty Budhi Utami, "Kebijakan Hukum Pidana Dalam Menanggulangi Tindak Pidana Illegal Logging”, Law Reform, Volume 3, Nomor 1, 2007, hlm, 3. 
instrumen hukum untuk menanggulangi tindak pidana illegal logging. ${ }^{14}$ Yang dimaksud dengan illegal logging berdasarkan Inpres Nomor 5 Tahun 2001, tentang Pemberantasan Penebangan Kayu Ilegal (Illegal Logging) dan Peredaran Hasil Hutan Ilegal. ${ }^{15}$

Sebelum berlakunya Undang-Undang Nomor 41 Tahun 1999 tentang Kehutanan, menebang, memotong, mengambil dan membawa kayu hasil hutan tanpa ijin dari pejabat yang berwenang dikenakan pasal-pasal dalam KUHP, namun setelah berlakunya UndangUndang Nomor Tahun 1999 Tentang Kehutanan terhadap perbuatan memanfaatkan kayu hasil hutan tanpa ijin pihak yang berwenang tersebut dikenakan pidana sebagaimana tercantum dalam Pasal 50 jo. Pasal 78 UU No. 41 tahun 1999 yang ancaman pidananya lebih berat dibandingkan dengan apabila dikenai pasal-pasal dalam KUHP. Setelah berlakunya Nomor 18 Tahun 2013 Tentang Pencegahan dan Pemberantasan Perusakan Hutan, ancaman pidananya lebih berat lagi dari undang-undang sebelumnya sebagaimana diatur dalam Pasal 82 sampai dengan Pasal 106.

Ancaman sanksi pidana yang diatur dalam Pasal 108 Undang-Undang No. 18 Tahun 2013 tentang Pencegahan dan Pemberantasan Perusakan Hutan menyatakan "selain penjatuhan sanksi pidana sebagaimana dimaksud dalam Pasal 82, Pasal 84, Pasal 94, Pasal 96, Pasal 97 huruf a, Pasal 97 huruf b, Pasal 104, Pasal 105, atau Pasal 106 dikenakan juga uang pengganti, dan apabila tidak terpenuhi, terdakwa dikenai hukuman penjara yang lamanya tidak melebihi ancaman maksimum dari pidana pokok sesuai dengan ketentuan dalam Undang-undang ini dan lama pidana sudah ditentukan dalam putusan pengadilan". Artinya sanksi pidana yang diatur dalam Pasal 108 Undang-Undang Nomor 18 Tahun 2013 bersifat kumulatif yaitu jika ada beberapa jenis pidana pokok yang diancamkan dalam suatu ketentuan hukum pidana, maka hakim harus menjatuhkan keseluruhannya. ${ }^{16}$

Penjatuhan pidana uang pengganti sebagaimana diatur dalam Pasal 108 UndangUndang No. 18 Tahun 2013 penting dilakukan karena kerusakan hutan akibat penebangan liar tanpa ijin serta perdagangan kayu hasil illegal logging yang merambah luar negeri dengan harga jual yang tinggi membuat siapa pun tergiur untuk melakukannya. ${ }^{17}$

14 Fransiska Novita Eleanora, “Tindak Pidana Illegal Logging Menurut Undang-Undang Nomor 32 Tahun 2009 Tentang Perlindungan dan Pengelolaan Lingkungan Hidup", Jurnal Hukum Adil, Vol. 3 No.2, 2012, hlm. 219.

15 Ni Luh Ketut Dewi Yani Putri dan I Ketut Mertha, "Kejahatan dan Penegakan Hukum Tindak Pidana Illegal Logging Guna Mengatasi Deforestasi Hutan Melalui Sistem Peradilan Pidana", Kertha Wicara, Vol. 07, No. 01, Jan 2018, hlm. 5.

16 Lainul iksan, dan Ibrahim, "Kebijakan Hukum Pidana dalam Menanggulangi Tindak Pidana Illegal Logging di Provinsi Jambi (Analisis Pasal 50 Dan Pasal 78 Undang-Undang Nomor 41 Tahun 1999 Tentang Kehutanan)", Legalitas, Volume VIII, Nomor 1, Juni 2016, hlm. 114.

17 Mohammad Taufik Makarao dan Abdul Muis Yusuf, Hukum Kehutanan di Indonesia, Jakarta: Rineka Cipta, 2011, hlm. 3 . 
Sanksi pidana uang pengganti tersebut dalam putusan Pengadilan Negeri Waikakubak tidak mengimplementasikan dari Pasal 108. Putusan Hakim Pengadilan Negara tersebut menjatuhkan pidana sesuai Pasal 82 ayat (1) huruf b Undang-Undang Nomor 18 Tahun 2013 yang berkaitan dengan penebangan pohon dalam kawasan hutan tanpa memiliki izin yang dikeluarkan oleh pejabat yang berwenang, tanpa diikuti dengan penjatuhan sanksi pidana uang pengganti yang termuat dalam Pasal 108 Undang-Undang Nomor 18 Tahun 2013, sehingga berarti adanya kesenjangan antara das sollen dan das sein yaitu kesenjangan antara teori dan kenyataan di lapangan. Barda Nawawi Arief, perlindungan terhadap korban kejahatan pada dasarnya merupakan bagian integral dari hak asasi korban kejahatan. ${ }^{18}$ Sebenarnya tuntutan untuk memberikan perlindungan bagi korban kejahatan dalam bentuk pembayaran uang pengganti dimaksudkan untuk mengambil seluruh keuntungan yang diperoleh dari hasil tindak pidana kehutanan dan dipergunakan untuk penanaman kembali hutan yang telah ditebang.\

Berdasarkan uraian latar belakang masalah tersebut di atas, maka pokok permasalahan yang dikemukakan adalah sebagai berikut: Bagaimana kebijakan hukum pidana terkait sanksi pidana berupa pembayaran uang pengganti terhadap pelaku tindak pidana illegal logging dalam Pasal 108 Undang-Undang Nomor 18 Tahun 2013? dan Bagaimanakah kebijakan Asas Ultimum Remedium dalam penegakan tindak pidana illegal logging Menurut Undang-Undang Nomor 32 Tahun 2009?

\section{METODE PENELITIAN}

Penelitian ini menggunakan tipologi penelitian hukum normatif khususnya yang berkaitan dengan Tindak pidana illegal logging. Hasil kajian norma-norma hukum dari inventarisasi hukum positif tersebut dapat membantu untuk mendapatkan pandangan yang tepat tentang formulasi hukum pidana dalam penyelesaian kasus penebangan liar. Hal ini akan menjadi salah satu produk analisa abstraksi dari norma hukum positif. ${ }^{19}$ Peter Mahmud Marzuki, ${ }^{20}$ menyatakan bahwa penelitian hukum merupakan proses untuk menemukan aturan hukum, prinsip-prinsip hukum, maupun doktrin-doktrin hukum guna menjawab isu hukum yang dihadapi. Selanjutnya, dalam penelitian hukum terdapat beberapa pendekatan. Dengan pendekatan tersebut, peneliti akan mendapatkan dari berbagai aspek mengenai isu yang

18 Barda Nawawi Arief, Masalah Penegakan Hukum dan Kebijakan Hukum Pidana dalam Penanggulangan Kejahatan, Jakarta: Prenada Media Group, 2008, hlm. 62.

19 Soentandyo Wingyosoebroto, Penelitian Hukum, Surabaya: Pusat Studi Hukum dan Pembangunan Fakultas Hukum Universitas Airlangga, 1974, hlm. 1,7, dan 8

20 Peter Mahmud Marzuki, Penelitian Hukum, Jakarta: Kencana, 2005, hlm. 35. 
sedang dicoba untuk dicari jawabnya. Pendekatan-pendekatan yang digunakan di dalam penelitian hukum adalah pendekatan undang-undang (statute approach), Pendekatan konsep (Conceptual Approach) dan pendekatan kasus (case approach). Pendekatan perundangan-undangan diperlukan guna mengkaji lebih lanjut Tindak pidana sengketa pertanahan. Sedangkan pendekatan konseptual, digunakan untuk memahami konsep pembaharuan hukum pidana, dalam memahami penerapan sanksi pidana sengketa pertanahan yang akan datang; sehingga diharapkan penormaan dalam aturan hukum dalam mengkaji serta menganalisis kerangka pikir atau kerangka konseptual maupun landasan teoritis sesuai dengan tujuan penelitian ini. ${ }^{21}$

\section{ANALISIS DAN PEMBAHASAN}

\section{Sanksi Pidana Pembayaran Uang Pengganti Terhadap Pelaku Tindak Pidana Illegal Logging Dalam Pasal 108 Undang-Undang Nomor 18 Tahun 2013}

Dalam UU Nomor 18 tahun 2013 terdapat pidana berupa pembayaran uang pengganti yang harus dibayar kepada korban dalam hal ini bukan individu melainkan negara. ${ }^{22}$ Dihubungkan dengan perbuatan perusakan hutan, dimana negara yang mengalami/dan menderita kerugian sehingga Negara dari sudut viktimologi adalah pula korban, dan yang menyebabkannya (yaitu terdakwa di depan sidang Pengadilan) dituntut untuk memberikan suatu ganti kerugian yang menurut istilah UU Nomor 18 Tahun 2013 adalah Uang Pengganti, Tampak negara adalah sebagai korban, dan dengan UU Nomor 18 tahun 2013 negara sebagai korban telah terlebih dahulu diperhatikan kepentingannya dalam suatu proses pidana. Pada hakikatnya ganti rugi bukan lagi monopoli proses perdata semata-mata, tetapi juga sudah menjadi pengertian yang terletak dalam lapangan hukum publik yaitu dalam hal ini dalam lapangan hukum pidana.

Jadi undang-undang sendiri ada menyebutkan tentang uang pengganti maupun uang ganti rugi atau ganti kerugian. Istilah-istilah ini mana yang paling tepat, maka karena UU Nomor 18 Tahun 2013, Pasal 108 tidak menggunakan istilah uang ganti rugi atau ganti kerugian, tetapi menggunakan istilah uang pengganti, dan inilah yang tepat bila kita berbicara tentang UU Nomor 18 Tahun 2013 dengan demikian istilah uang pengganti ada juga dalam Pasal 108 UU Nomor 18 Tahun 2013 selain Undang-Undang No. 31 Tahun 1999 Tentang Pemberantasan Tindak Pidana Korupsi.

21 Ibid, hlm. 133.

22 Muladi, Barda Nawawi Arief, Bunga Rampai Hukum Pidana, Bandung: Alumni, 1992, hlm. 87. 
Menurut Patti Peilohy,23 ada persamaan dan perbedaan antara pengertian uang pengganti dan uang ganti rugi. Perbedaannya bahwa:

1. Bila yang menyebabkan kerugian itu adalah seseorang dan ditujukan kepada kerugian negara, maka disebut membayar uang pengganti dan bukan membayar uang ganti rugi (Pasal 108 UU No. 18 tahun 2013).

2. Bila yang menyebabkan kerugian adalah:

a. Negara/Pejabat/Petugas karena lalai memenuhi ketentuan KUHP. maka disebut membayar ganti rugi dan bukan membayar uang pengganti (Pasal 95 KUHAP),

b. Seseorang pada orang lain, yang sebenarnya merupakan proses dan tuntutan perdata, tetapi oleh KUHAP diperkenankan melakukan penggabungan dengan proses dan tuntutan pidana, maka disebut membayar ganti rugi dan bukan membayar uang pengganti (Pasal 95 KUHP).

3. Baik pada orang maupun pada negara, yaitu pembayaran ini dilakukan karena syarat khusus yang diperjanjikan dalam putusan hakim, bila tidak dipenuhi disebut membayar ganti rugi dan bukan membayar uang pengganti (Pasal $14 \mathrm{c}$ angka $1 \mathrm{KUHP}$ ).

Persamaannya adalah bahwa baik uang pengganti maupun uang ganti rugi dilihat dari tujuan dan fungsinya adalah sama, yaitu:

a. Tujuannya sebagai suatu pergantian, yaitu memberikan pergantian terhadap suatu kerugian yang telah terjadi, untuk mencapai keseimbangan seperti semula,

b. Fungsinya: Dari segi fungsinya adalah sama yaitu sama-sama berfungsi sebagai suatu penghukuman yaitu uang pengganti merupakan suatu hukuman pokok sebagaimana tersebut dalam Pasal 108 UU Nomor 18 Tahun 2013, uang ganti rugi sebagaimana tersebut dalam Pasal 95 KUHAP adalah sebagai hukuman terhadap pejabat/petugas negara yang dalam tugasnya lalai memenuhi ketentuan perundangan, kekeliruan tentang orangnya maupun tentang penerapan hukumnya.

Demikian juga uang ganti rugi dalam Pasal 98 KUHAP adalah sebagai hukuman yang dijatuhkan Pengadilan di samping hukuman pidana, demikian pula uang ganti rugi dalam Pasal $14 \mathrm{c}$ angka 1 KUHP adalah juga sebagai suatu hukuman karena lalai memenuhi syarat khusus dalam suatu putusan Pengadilan. Pidana pembayaran uang pengganti merupakan konsekuensi dan akibat tindak pidana kehutanan yang dapat merugikan keuangan negara atau perekonomian negara, sehingga untuk mengembalikan kerugian tersebut diperlukan sarana yuridis yakni dalam bentuk pembayaran uang pengganti. Karena hutan merupakan aset negara yang apabila rusak juga dibutuhkan uang dari negara untuk mengembalikan bentuk hutan seperti keadaan semula. Uang pengganti merupakan suatu bentuk hukuman

23 M.W. Patti Peilohy, Antara Tuntutan Jaksa Penuntut Umum dan Putusan Hakim/Pengadilan Mengenai pembayaran Uang Penganti Bagian I, Ujung Pandang: Dipajaya, 1994, hlm. 21 
(pidana) pokok dalam tindak pidana kehutanan. Pada hakikatnya baik secara hukum maupun doktrin, hakim diwajibkan selalu menjatuhkan pidana pokok tersebut. sehingga juga perlu diperhatikan oleh hakim untuk memutuskan pembayaran uang pengganti tersebut berkaitan dengan kerugian keuangan negara yang timbul akibat dari kerusakan hutan ini, walaupun kerugian keuangan negara itu secara tidak langsung. Dalam hal ini kerugian negara tersebut harus dipulihkan, salah satu cara yang dapat dipakai guna memulihkan kerugian negara tersebut adalah dengan mewajibkan terdakwa yang terbukti dan meyakinkan telah melakukan tindak pidana kehutanan untuk mengembalikan kepada negara hasil kejahatan kehutanannya tersebut dalam wujud uang pengganti. Terdakwa perkara kejahatan kehutanan yang telah terbukti dan meyakinkan melakukan tindak pidana kehutanan terbebas dari kewajiban untuk membayar uang pengganti apabila uang pengganti tersebut dapat dikompensasikan dengan nilai komersial dari hasil hutan yang dirusak yang dinyatakan dirampas untuk negara atau terdakwa sama sekali tidak menikmati hasil komersial hasil hutan tersebut. ${ }^{24}$

Berdasarkan pemikiran yang demikian dapat diketahui bahwa istilah "uang pengganti" menurut Pasal 108 UU Nomor 18 Tahun 2013 Tentang "Pencegahan dan Pemberantasan Perusakan Hutan", sesungguhnya adalah suatu pengertian ganti rugi menurut proses perdata, yang oleh UU Nomor 18 Tahun 2013 pengertian dan proses perdata ini dimasukkan ke dalam menjadi proses pidana, sebagaimana halnya dengan penempatannya dalam Pasal 108 UU No. 18 tahun 2013 sebagai suatu sanksi pidana. ${ }^{25}$

Proses alur mengenai pembayaran uang pengganti Jika terpidana tidak membayar uang pengganti dalam waktu 1 bulan sejak putusan berkekuatan hukum tetap, maka harta bendanya dapat disita oleh jaksa dan dilelang untuk menutupi uang pengganti tersebut. Jika harta benda terpidana belum juga cukup untuk membayar uang pengganti, ia dipidana dengan pidana penjara selama 2 tahun. ${ }^{26}$

\section{Asas Ultimum Remedium dalam Penegakan Hukum Tindak Pidana Illegal Logging Menurut Undang-Undang Nomor 32 Tahun 2009}

24 Deasy Soeikromo, "Ketentuan Hukum Pidana Terhadap Praktik Illegal Logging dan Upaya Pelestarian Lingkungan Hidup di Indonesia", Jurnal Hukum Unsrat, Vol. 21, No. 5, Januari 2016, hlm 9.

25 Masagus Zunaidi Trisna Putra, "Upaya Reserse Kriminal Khusus dalam Penanggulangan Tindak Pidana Pembalakan Liar (Illegal Logging) di Wilayah Hukum Polda Lampung", POENALE: Jurnal Bagian Hukum Pidana, Vol. 6, No. 5, 2018, hlm 3.

26 Ady TD Achmad, "Kalau Terpidana Tak Sanggup Bayar Uang Pengganti”, HukumOnline.com, https://www.hukumonline.com/berita/baca/lt58cf9c439d3b4/kalau-terpidana-tak-sanggup-bayaruang-pengganti/, diakses pada tanggal 20 November 2020. 
Fakta terjadinya kerusakan lingkungan hidup di Indonesia ini menunjukkan bahwa upayaupaya perlindungan lingkungan hidup melalui sanksi administratif melalui teguran, penghentian sementara, dan pencabutan izin perusahaan kurang efektif dalam mengurangi atau menghentikan pencemaran dan kerusakan lingkungan hidup di Indonesia. ${ }^{27}$ Demikian pula tahapan berikutnya pemberian sanksi perdata berupa ganti rugi lingkungan hidup juga belum optimal mengurangi pencemaran dan kerusakan lingkungan hidup di Indonesia. Kondisi ini telah menggeser penerapan hukum pidana lingkungan hidup dari ultimum remedium atau penerapan hukum pidana lingkungan hidup sebagai upaya terakhir dalam mengurangi pencemaran dan perusakan lingkungan hidup menjadi penerapan primum remedium atau penerapan hukum pidana lingkungan hidup sebagai upaya utama dalam mengurangi pencemaran dan perusakan lingkungan hidup di Indonesia. ${ }^{28}$

Penegakan hukum lingkungan kepidanaan bersifat represif untuk dapat menindak pelaku (pencemar) yang terbukti secara meyakinkan bersalah dengan memberi pidana penjara dan/atau denda berdasarkan putusan hakim dalam menegakkan peraturan/undang-undang lingkungan. Hukum lingkungan sebagaimana halnya hukum pidana termasuk ke dalam hukum publik. ${ }^{29}$ Sanksi pidana lingkungan dalam UndangUndang Nomor 32 Tahun 2009 dapat diterapkan pada kejahatan lingkungan, karena menimbulkan kerugian besar bagi korban.

Dalam kajian teori hukum pidana, ada pendapat yang menyatakan bahwa sanksi pidana merupakan ultimum remedium terhadap setiap pelanggaran lingkungan. Pendapat ini didasarkan pemahaman bahwa pengelolaan lingkungan merupakan urusan pemerintah yang berwujud sebagai tindakan administrasi. Tindakan administrasi ini berawal pada penetapan izin oleh instansi atau lembaga yang berwenang. Apabila terjadi pelanggaran, maka pelanggaran itu merupakan pelanggaran administratif dan para pelanggarnya dapat dikenakan sanksi administratif. 30

Menurut pendapat ini, tindakan pertama yang diterapkan terhadap para pencemar adalah sanksi administrasi, kemudian sanksi perdata berupa pembayaran sejumlah ganti rugi atas kerugian materiil yang dialami oleh pihak korban. Sanksi pidana baru akan diterapkan kepada pihak pencemar apabila sanksi administrasi dan sanksi perdata tidak

27 Winarno, Budyatmojo, "Penegakkan Hukum Tindak Pidana Illegal Loging (Antara Harapan dan Kenyataan)", Yustisia, Vol. 2 No. 2, Mei - Agustus 2013, hlm. 95.

28 Andi Hamzah, Penegakan Hukum Lingkungan, Jakarta: Sinar Grafika, 2008, hlm. 58.

29 St. Munadjat Danusaputro, dalam Teguh Sulistia dan Aria Zurnetti, Hukum Pidana Horizon Baru Pasca Reformasi, Jakarta: PT RajaGrafindo Persada, 2011, hlm. 170

30 Ibid., hlm. 171. 
mampu berfungsi dengan baik. ${ }^{31}$ Jadi ada tahapan penjatuhan sanksi kepada pencemar dalam mekanisme penegakan hukum lingkungan. Sanksi pidana merupakan alternatif terakhir atau sarana hukum pamungkas sebagai ultimum remedium untuk menanggulangi pelanggaran hukum. Berlakunya Undang-Undang Nomor 32 Tahun 2009, dikenal jenis sanksi yang dapat dikenakan kepada pelaku Tindak Pidana Lingkungan, yaitu:

\section{Jenis Sanksi}

Sanksi Pidana

Jenis sanksi pidana yang digunakan hanya pidana pokok berupa penjara, dan denda; tidak ada tindak pidana yang diancam dengan pidana kurungan. Tidak adanya pidana kurungan ini disebabkan semua Tindak Pidana Lingkungan menurut Undang-Undang Nomor 32 Tahun 2009 dikualifikasikan sebagai "kejahatan". Walaupun menurut pola yang dianut selama ini (di dalam/di luar KUHP) bisa saja suatu kejahatan diancam dengan pidana kurungan.

\section{Sanksi "Tindakan Tata Tertib"}

Undang-Undang Nomor 32 Tahun 2009 membawa perubahan paradigma terhadap hukum pidana, yang sebelumnya menganut teori bahwa hanya individu atau orang perorangan yang dapat dihukum dengan sanksi pidana, sedangkan badan hukum karena dia tidak bisa melakukan kejahatan, tidak dapat dijatuhi sanksi pidana. Undang-Undang Perlindungan dan Pengelolaan Lingkungan Hidup mengakui tentang tanggung jawab korporasi sebagaimana diatur dalam Pasal 116 sampai Pasal 119 Undang-Undang Nomor 32 Tahun 2009.

Berdasarkan Pasal 119 Undang-Undang Nomor 32 Tahun 2009, jika tindak pidana dilakukan oleh badan usaha, tindak pidana bisa dijatuhi hukuman pokok berupa denda dan hukuman tambahan berupa tindakan tata tertib, (Pasal 119 Undang-Undang Nomor 32 Tahun 2009), sebagai berikut:
a. perampasan keuntungan yang diperoleh dari tindak pidana;
b. penutupan seluruh atau sebagian tempat usaha dan/atau kegiatan;
c. perbaikan akibat tindak pidana;
d. pewajiban mengerjakan apa yang dilalaikan tanpa hak; dan/atau
e. penempatan perusahaan di bawah pengampuan paling lama 3 (tiga) tahun.

31 Sitti Sundari Rangkuti, dalam Teguh Sulistia dan Aria Zurnetti, Ibid., hlm. 171. 


\section{Sistem Ancaman Pidana dan Lamanya Pidana}

Delik inti atau delik utama menurut Undang-undang Nomor 32 Tahun 2009 ialah "pencemaran dan/atau perusakan lingkungan hidup" yang diatur dalam Pasal 98 (untuk delik dolus/sengaja) dan dalam Pasal 99 (untuk delik culpa). Maksimum pidananya ialah:

a. Untuk delik dolus; dipidana dengan pidana penjara paling singkat 3 (tiga) tahun dan paling lama 10 (sepuluh) tahun dan denda paling sedikit Rp 3.000.000.000,00 (tiga miliar rupiah) dan paling banyak Rp 10.000.000.000,00 (sepuluh miliar rupiah) (Pasal 98);

b. Untuk delik culpa; dipidana dengan pidana penjara paling singkat 1 (satu) tahun dan paling lama 3 (tiga) tahun dan denda paling sedikit Rp 1.000.000.000,00 (satu miliar rupiah) dan paling banyak Rp 3.000.000.000,00 (tiga miliar rupiah) (Pasal 99);

\section{Sistem Perumusan Pidana}

Menurut Undang-Undang Nomor 32 Tahun 2009 di atas, lebih berat jika dibandingkan dengan Undang-Undang Nomor 23 Tahun 1997. Bila dibandingkan pada perumusan ancaman pidana sebagaimana diuraikan di atas, tampak bahwa Undang-Undang Nomor 32 tahun 2009 menganut sistem perumusan kumulatif kecuali hanya satu pasal yang menganut sistem perumusan alternatif yaitu Pasal 112. Berbeda halnya dengan Undang-Undang Nomor 23 tahun 1997 yang menganut sistem perumusan kumulatif. Dalam perundangundangan lingkungan sektoral, maksimum ancaman pidananya kebanyakan masih berorientasi pada Undang-Undang Nomor 4 tahun 1982, walaupun ada beberapa penyimpangan untuk maksimum ancaman pidana denda. Sistem perumusan ancaman pidananya juga kebanyakan sesuai dengan Undang-Undang Nomor 4 Tahun 1982 yaitu sistem kumulatif alternatif, walaupun ada juga yang dirumuskan dengan sistem kumulatif (Pasal 40 Undang-Undang Nomor 5 Tahun 1990 dan ada yang menggunakan sistem alternatif (Pasal 119 dan 120 Undang-Undang Nomor 21 Tahun 1992.

Adapun sanksi pidana yang dapat dijatuhkan pada pelaku kejahatan atau pelanggaran di bidang konservasi keanekaragaman hayati secara umum dapat dikenai ketentuan yang termuat dalam Undang-Undang Nomor 32 Tahun 2009, dimuat dari Pasal 98 sampai Pasal 119 berupa pidana penjara dan denda sedangkan dalam Undang-Undang Nomor 41 Tahun 1999 sanksi pidana penjara dan denda yaitu terdapat dalam Pasal 78. Oleh karena berfungsi sebagai umbrella provision, maka ketentuan sanksi pidana yang termuat 
dalam Undang-Undang Nomor 32 Tahun 2009 dan Undang-Undang Nomor 41 Tahun 1999 terhadap sanksi pidana yang terdapat dalam Undang-Undang Nomor 5 Tahun 1990 berlaku adagium “Lex Specialis Derogat Legi Genelrali atau Lex Posterior Derogat Legi Periori”

Sehubungan dengan uraian yang dikemukakan di atas, maka penegakan hukum lingkungan di Indonesia mencakup penataan dan penindakan (compliance and enforcement) yang meliputi bidang hukum administrasi negara, bidang hukum perdata dan bidang hukum pidana, ${ }^{32}$ artinya dalam penegakan hukum lingkungan harus ditempuh terlebih dahulu melalui bidang hukum administrasi, adapun penyelesaian melalui bidang hukum pidana adalah merupakan upaya terakhir. Dalam Undang-Undang Nomor 32 Tahun 2009 tentang Perlindungan dan Pengelolaan Lingkungan Hidup dikenal dengan asas ultimum remedium, namun sebelum berlakunya Undang-Undang Nomor 32 Tahun 2009 Tentang Perlindungan dan Pengelolaan Lingkungan Hidup, sebelumnya berlaku Undang-Undang Nomor 4 Tahun 1982 tentang Pokok-Pokok Pengelolaan Lingkungan Hidup yang kemudian diperbaharui dengan Undang-Undang Nomor 23 Tahun 1997 tentang Pengelolaan Lingkungan Hidup, dikenal asas subsidaritas kemudian asas subsidaritas ini dihapus dan diganti dengan asas ultimum remedium sebagaimana tercantum pada penjelasan umum angka 6 UndangUndang Nomor 32 Tahun 2009 tentang Perlindungan dan Pengelolaan Lingkungan Hidup, alasan penghapusan asas subsidaritas dapat dibaca pada naskah akademik RUU UUPPLH, bahwa asas subsidaritas merupakan salah satu masalah pada penerapan atau praktik hukum lingkungan karena ketidakjelasan makna asas tersebut, oleh karena itu kata asas subsidaritas dihapus dan diganti dengan asas ultimum remedium dengan dipertegas bahwa asas tersebut hanya dapat diterapkan pada delik formil tertentu yaitu pelanggaran terhadap baku mutu air limbah, emisi dan gangguan. ${ }^{33}$

Asas ultimum remedium diatur dalam penjelasan angka 6 Undang-Undang Nomor 32 Tahun 2009 tentang Perlindungan dan Pengelolaan Lingkungan Hidup, yang berbunyi:

Penegakan hukum pidana dalam Undang-Undang ini memperkenalkan ancaman hukuman minimum di samping maksimum, perluasan alat bukti, pemidanaan bagi pelanggaran baku mutu, keterpaduan penegakan hukum pidana, dan pengaturan tindak pidana korporasi. Penegakan hukum pidana lingkungan tetap memperhatikan asas ultimum remedium yang mewajibkan penerapan penegakan hukum pidana sebagai upaya terakhir setelah penerapan penegakan hukum administrasi dianggap tidak berhasil. Penerapan asas ultimum remedium ini hanya

32 M. Daud Silalahi, Hukum Lingkungan Dalam Sistem Penegakan Hukum Lingkungan Indoensia, Bandung: PT. Alumni, 2014, hlm. 215.

33 Imam Budi Santoso, Taun, "Penerapan Asas Ultimum Remedium dalam Penegakan Hukum Pidana Lingkungan Hidup”, University Of Bengkulu Law Journal, Volume 3 Number 1, April 2018, hlm. 18. 
berlaku bagi tindak pidana formil tertentu, yaitu pemidanaan terhadap pelanggaran baku mutu air limbah, emisi, dan gangguan.

Pada intinya asas ultimum remedium ini mengatur tentang penegakan hukum pidana lingkungan sebagai upaya terakhir setelah penerapan penegakan hukum administrasi dianggap tidak berhasil. Namun asas ultimum remedium ini jika dikaitkan dengan prinsip umum dalam hukum pidana terdapat pertentangan, yaitu Asas Legalitas.

Asas legalitas tercantum dalam Pasal 1 ayat (1) KUHP, kalau kata-katanya yang asli dalam bahasa Belanda disalin ke dalam bahasa Indonesia kata demi kata, maka akan berbunyi: "Tiada suatu perbuatan ( feit) yang dapat dipidana, selain berdasarkan kekuatan ketentuan perundang-undangan pidana yang mendahuluinya". ${ }^{34}$ Artinya ketika ada peraturan perundang-undangan yang mengatur tentang suatu tindak pidana, maka terhadap orang yang melanggar aturan tersebut berdasarkan asas legalitas harus dipidana, demikian pula dengan yang diatur dalam Pasal 100 Undang-Undang Nomor 32 Tahun 2009 tentang Perlindungan dan Pengelolaan Lingkungan Hidup, yaitu:

(1) Setiap orang yang melanggar baku mutu air limbah, baku mutu emisi, atau baku mutu gangguan dipidana, dengan pidana penjara paling lama 3 (tiga) tahun dan denda paling banyak Rp3.000.000.000,00 (tiga miliar rupiah).

(2) Tindak pidana sebagaimana dimaksud pada ayat (1) hanya dapat dikenakan apabila sanksi administratif yang telah dijatuhkan tidak dipatuhi atau pelanggaran dilakukan lebih dari satu kali.

Dalam Pasal 100 ayat (1) tersebut sudah jelas rumusan tindak pidana dan hukuman yang diterima bagi orang yang melanggar pasal tersebut, dan jika dikaitkan dengan asas legalitas maka ketika ada yang melanggar pasal tersebut seketika itu pula pidana berjalan, ditambah dengan tindak pidana dalam Undang-Undang Nomor 32 Tahun 2009 tentang Perlindungan dan Pengelolaan Lingkungan Hidup adalah merupakan kejahatan, sebagaimana diatur dalam Pasal 97, yaitu: “Tindak pidana dalam undang-undang ini merupakan kejahatan", maka sedikit keliru penulisan kata "pelanggaran" dalam Pasal 100 ayat (2) di atas, yang seharusnya berdasarkan Pasal 97 tindak pidana ini merupakan kejahatan.

Jika dilihat dari sumber peniadaan pidana, maka dasar peniadaan pidana dibagi atas dua kelompok, yaitu yang tercantum dalam undang-undang dan yang lain terdapat di

34 Andi Hamzah, Hukum Pidana, Jakarta: PT. Sofmedia, 2015, hlm. 49. 
luar undang-undang diperkenalkan oleh yurisprudensi dan doktrin. ${ }^{35}$ Yang tercantum dalam undang-undang dapat dibagi lagi atas: yang umum (terdapat di dalam ketentuan umum buku 1 KUHP) dan berlaku atas semua rumusan delik. Yang khusus, tercantum dalam pasal tertentu yang berlaku untuk rumusan-rumusan delik itu saja. Adapun jika dikaitkan dengan pelanggaran Pasal 100 ayat (1) Undang-Undang Nomor 32 Tahun 2009 tentang Perlindungan dan Pengelolaan Lingkungan Hidup yang terdapat pidana di dalamnya, maka jika Pasal 100 ayat (1) tersebut akan ditiadakan pidananya harus ada dasar yang kuat, sebagaimana diatur dalam hukum pidana umum yaitu KUHP, adapun rincian dasar peniadaan pidana yang umum itu terdapat di dalam: ${ }^{36}$

1. Pasal 44: tidak dapat dipertanggungjawabkan;

2. Pasal 48: daya paksa;

3. Pasal 49: ayat (1) pembelaan terpaksa;

4. Pasal 49: ayat (2) pembelaan terpaksa yang mel

5. Pasal 51: ayat (1) menjalankan perintah jabatan yang berwenang;

6. Pasal 51: ayat (2) menjalankan perintah jabatan yang tidak berwenang jika bawahan itu dengan itikad baik memandang atasan yang bersangkutan sebagai berwenang.

Dasar-dasar tersebut di atas adalah merupakan dasar umum terhadap peniadaan suatu tindak pidana, sehingga jika dikaitkan dengan asas ultimum remedium yang menjadikan pidana sebagai upaya terakhir sangat tidak sesuai dengan dasar peniadaan pidana. Dalam asas ultimum remedium sesuai yang diatur dalam penjelasan angka 6 UndangUndang Nomor 32 Tahun 2009 tentang Perlindungan dan Pengelolaan Lingkungan Hidup, mewajibkan penerapan penegakan hukum pidana sebagai upaya terakhir setelah penerapan penegakan hukum administrasi dianggap tidak berhasil, selain itu disebutkan juga dalam Pasal 100 ayat (2) yang berbunyi "Tindak pidana sebagaimana dimaksud pada ayat (1) hanya dapat dikenakan apabila sanksi administratif yang telah dijatuhkan tidak dipatuhi atau pelanggaran dilakukan lebih dari satu kali”.

Sedangkan menurut dasar peniadaan pidana tersebut, tidak mencantumkan setelah menjalani sanksi administrasi kemudian sanksi pidana menjadi gugur/tiada, perlu dibedakan antara aturan pidana dan aturan administrasi, keduanya merupakan ranah hukum yang berbeda dari segi pengaturannya, sanksi administrasi dikenakan jika ada

35 Ibid., hlm. 192.

36 Ibid. 
pelanggaran administrasi, demikian juga dengan sanksi pidana dikenakan terhadap perbuatan seseorang yang melawan hukum dan mempunyai kesalahan. Maka tidak serta merta ketika sanksi administrasi dijalankan, kemudian seseorang yang melakukan tindak pidana lepas dari pertanggungjawaban pidana, demikian pula sebaliknya, ketika seseorang yang melakukan tindak pidana kemudian dijatuhi hukuman pidana, tidak serta merta pula bebas dari sanksi administrasi. Sehingga dalam hal ini asas ultimum remedium yang diatur dalam penjelasan angka 6 kemudian diatur dalam Pasal 100 ayat (2) Undang-Undang Nomor 32 Tahun 2009 tentang Perlindungan dan Pengelolaan Lingkungan Hidup, sangat tidak mendasar untuk meniadakan pidana dalam Pasal 100 ayat (1) Undang-Undang Nomor 32 Tahun 2009 Tentang Perlindungan dan Pengelolaan Lingkungan Hidup, karena bertentangan dengan dasar peniadaan pidana dalam prinsip hukum pidana.

\section{KESIMPULAN}

Sanksi pidana pembayaran uang pengganti kepada korban sebagai bentuk kebijakan hukum pidana. Sebab selama ini dalam hukum pidana cenderung memberikan sanksi pidana untuk menjerakan pelaku, tetapi kurang berdampak pada korban. Korban yang dimaksud dalam hal ini adalah negara (bukan individu) sehingga akhirnya uang pengganti yang dibayarkan tersebut negara yang akan menerimanya. Sanksi pidana sebagai upaya penegakan hukum terakhir yang diterapkan setelah sanksi administrasi dan sanksi perdata dianggap tidak berhasil menyelesaikan illegal logging.

\section{Daftar Pustaka}

\section{Buku}

Arief, Barda Nawawi, Masalah Penegakan Hukum dan Kebijakan Hukum Pidana dalam Penanggulangan Kejahatan, Jakarta: Prenada Media Group, 2008.

Hamzah, Andi, Hukum Pidana, Jakarta: PT. Sofmedia, 2015. Penegakan Hukum Lingkungan, Jakarta: Sinar Grafika, 2008.

Makarao, Mohammad Taufik, Abdul Muis Yusuf, Hukum Kehutanan di Indonesia, Jakarta: Rineka Cipta, 2011.

Marzuki, Peter Mahmud, Penelitian Hukum, Jakarta: Kencana, 2005.

Moeljatno, Asas-Asas Hukum Pidana (Edisi Revisi), Jakarta: Rineka Cipta, 2015.

Muladi, Barda Nawawi Arief, Bunga Rampai Hukum Pidana, Bandung: Alumni, 1992. 
Murhaini, Suriansyah, Penegakan Hukum Terhadap Kerjahatan di Bidang Kehutanan, Yogyakarta: Laksbang Grafika, 2012.

Peilohy, M.W. Patti, Antara Tuntutan Jaksa Penuntut Umum dan Putusan Hakim/Pengadilan Mengenai pembayaran Uang Penganti Bagian I, Ujung Pandang: Dipajaya, 1994.

Silalahi, M. Daud, Hukum Lingkungan Dalam Sistem Penegakan Hukum Lingkungan Indoensia, Bandung: PT. Alumni, 2014.

Sulistia, Teguh, Aria Zurnetti, Hukum Pidana Horizon Baru Pasca Reformasi, Jakarta: PT RajaGrafindo Persada, 2011.

Wingyosoebroto, Soentandyo, Penelitian Hukum, Surabaya: Pusat Studi Hukum dan Pembangunan Fakultas Hukum Universitas Airlangga, 1974.

\section{Jurnal}

Bawono, Bambang Tri, Anis Mashdurohatun, "Penegakan Hukum Pidana di Bidang Illegal Logging Bagi Kelestarian Lingkungan Hidup Dan Upaya Penanggulangannya", Jurnal Hukum Fakultas Hukum Unissula, Vol XXVI, No. 2, Agustus 2011.

Eleanora, Fransiska Novita, “Tindak Pidana Illegal Logging Menurut Undang-Undang Nomor 32 Tahun 2009 Tentang Perlindungan dan Pengelolaan Lingkungan Hidup", Jurnal Hukum Adil, Vol. 3 No.2, 2012.

Fitriah, Nikmah, "Tinjauan Yuridis tentang Kriteria Pencemaran dan Perusakan Lingkungan Menurut UU No. 32 Tahun 2009 Tentang Pengelolaan Lingkungan Hidup", Halu Oleo Law Review, Volume 1 Issue 2, September 2017.

Haris, Oheo K., “Good Governance (Tata Kelola Pemerintahan Yang Baik) dalam Pemberian Izin oleh Pemerintah Daerah di Bidang Pertambangan", Yuridika, Volume 30 No 1, Januari 2015.

Herman, "Upaya Non Penal dalam Penanggulangan Tindak Pidana Korupsi”, Halu Oleo Law Review, Volume 2 Issue 1, March 2018.

Iksan, Lainul, Ibrahim, “Kebijakan Hukum Pidana dalam Menanggulangi Tindak Pidana Illegal Logging di Provinsi Jambi (Analisis Pasal 50 Dan Pasal 78 Undang-Undang Nomor 41 Tahun 1999 Tentang Kehutanan)", Legalitas, Volume VIII, Nomor 1, Juni 2016.

Kuswardani, Handrawan, Widhia Kusuma Wardhani, "Hak Reproduksi Perempuan dan Hukum Pidana", Halu Oleo Law Review, Volume 3 Issue 2, September 2019. 
Pratiwi, Bimbi, “Sistem Penegakan Hukum Terhadap Tindak Pidana Illegal Logging (Studi Di KPH Bojonegoro Perum Perhutani Unit II Jawa Timur Dan Kepolisian Resort Bojonegoro", Jurnal Hukum Fakultas Hukum Universitas Brawijaya, Mei 2015.

Putra, Masagus Zunaidi Trisna, “Upaya Reserse Kriminal Khusus dalam Penanggulangan Tindak Pidana Pembalakan Liar (Illegal Logging) di Wilayah Hukum Polda Lampung”, POENALE: Jurnal Bagian Hukum Pidana, Vol. 6, No. 5, 2018.

Putri, Ni Luh Ketut Dewi Yani, I Ketut Mertha, "Kejahatan dan Penegakan Hukum Tindak Pidana Illegal Logging Guna Mengatasi Deforestasi Hutan Melalui Sistem Peradilan Pidana", Kertha Wicara, Vol. 07, No. 01, Jan 2018.

Salam, Johnny, "Penanggulangan Kejahatan Illegal Logging di Provinsi Sulawesi Tengah", Tadulako Law Review, Volume 1 Issue 1, June 2016.

Santoso, Imam Budi, Taun, "Penerapan Asas Ultimum Remedium dalam Penegakan Hukum Pidana Lingkungan Hidup”, University Of Bengkulu Law Journal, Volume 3 Number 1, April 2018.

Soeikromo, Deasy, "Ketentuan Hukum Pidana Terhadap Praktik Illegal Logging dan Upaya Pelestarian Lingkungan Hidup di Indonesia", Jurnal Hukum Unsrat, Vol. 21, No. 5, Januari 2016.

Utami, Tuty Budhi, “Kebijakan Hukum Pidana Dalam Menanggulangi Tindak Pidana Illegal Logging”, Law Reform, Volume 3, Nomor 1, 2007.

Winarno, Budyatmojo, "Penegakkan Hukum Tindak Pidana Illegal Loging (Antara Harapan dan Kenyataan)", Yustisia, Vol. 2 No. 2, Mei - Agustus 2013.

\section{Situs web}

"Empat Kabupaten di Sultra Darurat Kerusakan Hutan", Kendari Pos, https://www.facebook.com/watch/?v=272751250178907, diakses pada tanggal 29 Mei 2020.

Achmad, Ady TD, “Kalau Terpidana Tak Sanggup Bayar Uang Pengganti”, HukumOnline.com, https://www.hukumonline.com/berita/baca/lt58cf9c439d3b4/kalau-terpidanatak-sanggup-bayar-uang-pengganti/, diakses pada tanggal 20 November 2020.

Arifin, Nurul, “Bagaimana Hutan Indonesia Sebagai Paru-Paru Dunia di Masa Depan?”, Good News From Indonesia, https://www.goodnewsfromindonesia.id/2018/01/12/ bagaimana-hutan-indonesia-sebagai-paru-paru-dunia-di-masa-depan, diakses pada tanggal 29 Mei 2020. 